\title{
Effect of An Educational Program on Nurses' Performance regarding Prevention of Venous Thromboembolism among Critically Ill Patients
}

Gehad Hussein Amin El-gendy ${ }^{1}$, Manal Hamed Mahmoud ${ }^{2}$ and Eman Sobhy Omran ${ }^{3}$

(1) B.Sc. of Nursing (2011), Medical Surgical Nursing, Faculty of Nursing, Benha University, Egypt (2)

Professor of Medical Surgical Nursing, Faculty of Nursing, Benha University, Egypt and (3) Lecturer of Medical Surgical Nursing, Faculty of Nursing, Benha University, Egypt

\begin{abstract}
Background: Venous thromboembolism in the form of deep venous thrombosis and pulmonary embolism is a leading cause of hospital related deaths worldwide with range between 10 and $30 \%$ and associated with additional morbidity and mortality. Aim of the study: Was to evaluate the effect of an educational program on nurses' performance regarding prevention of venous thromboembolism among critically ill patients. Design: Quasi experimental research design was used to achieve the objective of the current study. Setting: This study was conducted at Benha University Hospital in intensive care units (General, Coronary and Critical Care Unit). Sample: Convenient sample of 120 nurses included in the study. Tools: Two tools were used, I: An interview questionnaire to assess nurses' knowledge regarding prevention of venous thromboembolism, it consisted of two parts, part1: Demographic data for nurses, part 2: Nurses' knowledge related to venous thromboembolism and II: Observational checklist for the evaluation of nursing suffering from venous thromboembolism. Results: Majority of the nurses had unsatisfactory knowledge and practice regarding prevention of venous thromboembolism pre intervention program $(72.5 \%$ and $72.5 \%)$ respectively which improved immediately post program intervention to $(65.8 \%$ and $78.3 \%)$ respectively as $(\mathrm{P} \leq 0.001)$. Conclusion: The educational program has positive effect in improving nurses' performance (knowledge and practice) regarding prevention of venous thromboembolism among critically ill patients. Recommendations: Conducting continuous educational and training programs for nurses regarding prevention of venous thromboembolism among critically ill patients.
\end{abstract}

Key words: Critically ill Patients, Venous Thromboembolism, Nurses' Performance.

\section{Introduction}

Venous Thromboembolism (VTE) is an important cause of morbidity and mortality in critically ill patients. It is a disorder that includes deep vein thrombosis and pulmonary embolism. The risk of Deep Vein Thrombosis (DVT) and its prevention have been poorly characterized in this population. DVT occurs when a blood clot forms in a deep vein, usually in the lower leg, thigh, or pelvis. Pulmonary Embolism (PE) occurs when a clot breaks loose and travels through the bloodstream to the lungs (Lavery, 2021).

Critically ill patients are at high risk of DVT as patients are susceptible to both general risks factors of DVT as well as those specific to Intensive Care Unit (ICU) In addition, critical illness activates the coagulation cascade that may mediate the increased likelihood of DVT. Moreover, the prevalence of DVT and PE is underestimated in the ICU, as it is often clinically silent, especially in sedated and mechanically ventilated patients. ICU acquired 


\section{Effect of An Educational Program on Nurses' Performance regarding Prevention of Venous Thromboembolism among Critically Ill Patients}

thromboembolic events are difficult to such as advanced age, serious medical illnesses, recent surgical procedures, sepsis, paralysis, sedation, immobilization, vasopressors, trauma, heart failure, and central venous lines diagnose as they can mimic several other diseases (Tran, et al., 2019).

The mechanism behind DVT formation typically involves some combination of decreased blood flow rate, increased tendency to clot, changes to the blood vessel wall, and inflammation. Risk factors include recent surgery, older age, active cancer, obesity, infection, inflammatory diseases, antiphospholipid syndrome, personal history and family history of VTE, trauma, injuries, lack of movement, hormonal birth control, pregnancy, and the period following birth. VTE has a strong genetic component, accounting for approximately 50 to $60 \%$ of the variability in VTE rates (Crous-Bou, et al., 2016).Genetic factors include non-O blood type, deficiencies of Antithrombin, protein $\mathrm{C}$, and protein $\mathrm{S}$ and the mutations of factor $\mathrm{V}$ Leiden and prothrombin G20210A (Klarin, et al., 2019).

Interventions to prevent DVT begin at the time of admission and should be continued until patients' discharge. The role of critical care nurses in detecting and preventing DVT is important because observation and risk assessment of patients can result in early and prompt diagnosis and thus treatment with a consequent decrease in life-threatening complications. Accordingly, ICU nurses need to increase the effectiveness of assessment, apply timely preventive measures, and comply with the DVT prevention protocol (Schünemann, et al., 2018).
Nurses can positively affect outcomes in mechanical or physical DVT prophylaxis simply by educating patients regarding the importance of physical therapy and early movement through early ambulation, leg elevation, leg flexing, active and passive range of motion exercises. They are also being on the frontline of thrombosis prevention, by playing a crucial role in diagnosis and risk assessment, applying timely preventive methods and providing vital educational and psychological support for patients with venous thromboembolism, so skilled nursing intervention can be lifesaving (Haut, et al., 2017).

\section{Significance of the study}

Venous thromboembolism is a major and often unrecognised cause of patient's morbidity and mortality in hospitalized patients. PE accounts for 5-10\% of hospital deaths and is, therefore, often quoted as the most preventable cause of death in hospital. Hospitalized patients are at a 100 times greater risk than primary care patients and between 25 $30 \%$ of non-fatal VTEs occur in patients with prior hospitalization (Li, et al, 2021). In critically ill Egyptian patients DVT incidence rates varied from $6.6 \%$ to $27.3 \%$ ) (Mokadem \& El -Sayed, 2019).

The Deep vein thrombosis is a silent killer, which kills more people than AIDS, breast cancer, prostate cancer and road accidents combined (Elkattan \& Elderiny, 2017). Every year, over 4 million patients worldwide are affected by DVT. According to Centers for Disease Control (CDC), the precise number of people affected by DVT/PE is 300,000 to 6 00,000(1-10 per 1000) (Ageno, et al., 2021). 
In Egypt, more than one-third of all patients hospitalized for surgery or acute medical conditions are at high risk for developing VTE. Corrective measures are necessary for preventing VTE morbidity and mortality in these high risk patients. The DVT is a wide spread complication and important cause of hospital-related deaths worldwide. The study in Egypt is a part of a global initiative to uncover the incidence of high-risk surgical and medical patients and determine what proportion of these patients receives appropriate VTE prophylaxis (Shaaban, 2021).

\section{Aim of the study}

This study aimed to evaluate the effect of an educational program on nurses' performance regarding prevention of venous thromboembolism among critically ill patients.

\section{Research Hypotheses}

- Nurses' knowledge will be improved after implementation of an educational program for prevention of venous thromboembolism among critically ill patients.

- Nurses' practice will be improved after implementation of an educational program for prevention of venous thromboembolism among critically ill patients.

\section{Subjects and Methods}

\section{Research Design}

Quasi experimental research design was used.

\section{Setting}

The study was conducted in Intensive Care Units (General, Coronary and Critical Care Unit) at Benha University Hospital in Qualubia Governorate.

\section{Sample}

Convenient sample of 120 nurses included in the study.

\section{Exclusion criteria}

Nurses have work experience less than one year.

\section{Tool of data collection}

Two tools were used to collect data:

\section{Tool I: A structured interviewing} questionnaire:

It was developed by investigator and revised by supervisor staff, based on reviewing related literatures (Ahmed et al., 2015) (Mohammed, et al., 2018) \& (Eldosoky, 2018) and written in simple Arabic language, consisted of two parts:

Part one: Nurses' demographic data, this part concerned assessment of nurses' demographic characteristics. It composed of nine questions related to age, gender, residence, marital status, qualifications, years of experience, training courses and policies or booklet in your workplace.

Part two: Nurses' knowledge, this part designed to assess nurses' knowledge regarding venous thromboembolism and its prevention. It composed of 57 multiple choice questions related to the study.

\section{Scoring system}

All knowledge variables were weighted according to items included in each question. The answers of the questions were classified into two categories. The answer would have scored one mark for correct answer and would have scored zero for incorrect answer or if it was I don't know.

The score of total knowledge was classified as the following:

- Good: $\quad(\geq 80 \%$ correct answers).

- Average: (50 - <80\% correct answers).

- Poor: $\quad$ (<50\% correct answers).

Tool II: Observational checklist for nurses' practice:

Observational checklist included items about practical skills for venous 


\section{Effect of An Educational Program on Nurses' Performance regarding Prevention of Venous}

\section{Thromboembolism among Critically Ill Patients}

thromboembolism risk assessment, anticoagulant injection, leg measurements, applying compression stockings, active and passive range of motion exercises and assisting the patient with ambulation developed by the researcher guided by (Nettina, 2014) (Mokadem, et al., 2019) \& (Tamowicz, et al,.2019).

\section{The scoring system regarding practice}

Practice score for each answer was given as follows: one mark for each step correctly done, and zero for incorrectly done \&not done.

The total practices score was considered satisfactory if the score of the practices $\geq 85 \%$ and considered unsatisfactory if it is $<85 \%$.

\section{Content validity}

The validity of data collection tools and the program were revised and ascertained by a panel of five experts (jury) from medical surgical nursing department, Faculty of Nursing, Benha University (two professor of Medical Surgical Nursing and three assist professor of Medical Surgical Nursing). Their opinions were regarding the content, format, clarity, consistency, accuracy, comprehensive and relevancy of the tools. According to their opinion minor modifications were applied.

\section{Reliability of tools}

The researcher used test-retest methods to test the internal consistency of the tools, by administration of the same tools to the subjects under similar condition on two different occasions. Testing reliability of the developed tool was done statistically through Cronbach's Alpha test that was 0.93 for the nurses' knowledge questionnaire and 0.89 for the practical checklist and risk assessment.

\section{Ethical consideration}

The aim of the study was explained to all nurses and they were assured that all information was confidential and it would be used only for research purpose only. Nurses' consent was obtained to participate in the study. Nurses' privacy and data confidentiality had be respected. Nurses were informed that they were allowed to choose to participate or not in the study and they had the right to withdraw from the study at any time without giving any reasons.

\section{Pilot study}

A pilot study was conducted on $10 \%$ of all nurses that were included in the study from the total number of nurses (133) in order to test clarity, comprehensiveness and time on sources consuming for tools. Study tools were modified according to the results of pilot study. The nurses involved in the pilot study (13nurses) were excluded from the main study (the study sample) because there were no modifications done after conducting the pilot study.

\section{Field work}

The field work was performed over a period of six months started from the beginning of January, 2021 to the end of June, 2021; the data was collected from nurses in ICUs at Benha University Hospital through interview of them in sitting place after taking their acceptance to participate in the study and explaining the aim of the study. Total number the studied nurses was 120 nurses, they were divided into small groups (12 groups). Each group contained ten nurses in every session. Each group of nurses was decided the most convenient time; these times were determined by the nurses as the most suitable time during the day. The investigator was attended three days/weak from 3 PM o'clock to 5 PM o'clock. The investigator 


\section{Gehad Hussein Amin El-gendy, Manal Hamed Mahmoud and Eman Sobhy Omran}

met every group for four sessions. Two sessions for theory and two sessions for practice. Each session ranged between $30-45$ minutes, including the period of discussion. Each session started with brief summary about what had been given through the previous session, then the objectives of the new topics, taking into consideration the use of simple language to suite the level of all nurses' education.

Teaching methods during sessions included group discussion, instructions and demonstration. At the end of each session the nurses ask questions to correct any misunderstanding.

\section{Statistical analysis}

The collected data was analyzed, tabulated and presented in figures using the number and percentage distribution, mean and standard deviation using Statistical Package for Social Sciences (SPSS) version 20, Data were presented using proper statistical tests that were used to determine whether there significant differences or not and if there were positive correlation or not. The following statistical tests were used: Number and Percentage: Mean and Stander deviation (SD) and Chi-square $\mathbf{x}^{2}$ was used for qualitative data. Also P-value was used to determine significance of results as follows: $<0.05$ is statistically significant difference: $>0.05$ not statically significant difference and $<0.001$ it is highly significant difference.

\section{Results}

Table (1): Shows that $49.2 \%$ of them were in age group between 20-35 years old with a mean age of $28.82 \pm 1.36$ years, while $85.8 \%$ of them were females. As regards the residence, $60.8 \%$ of them lived in rural areas. Furthermore; $80.8 \%$ of the studied nurses were married. Regarding the qualification, $34.2 \%$ of the studied nurses were graduated from
Technical Nursing Institute. Moreover; 50.0\% of the studied nurses had 5-10 years of experience in ICU. Furthermore, 90.0\% of them didn't take any training course about methods of preventing venous thromboembolism. Finally, all of the studied nurses reported that there weren't found any policies, guides or booklet about preventing venous thromboembolism in their workplace.

Figure (1): Displays that, $9.2 \%$ of studied nurses had good knowledge regarding prevention of venous thromboembolism preprogram intervention which improved to $65.8 \%$ at post-program intervention phase. While, it was revealed that $72.5 \%$ of studied nurses had poor knowledge regarding prevention of VTE pre-intervention this improved to $21.7 \%$ postintervention phase.

Table (2): Clarifies that, mean score of studied nurses about total practices regarding prevention of venous thromboembolism pre and post-intervention was improved from 92.24 \pm 7.36 pre -program intervention to $155.58 \pm 6.33$ post program intervention. In addition, there were highly statistical differences between their mean scores pre -program intervention as compared to post program intervention $(\mathrm{p} \leq$ 0.001).

Table (3): Clarifies that, there was a statistically significant relation between total knowledge score regarding prevention of venous thromboembolism among critically ill patients and studied nurses' age pre and post program intervention as well as their qualification pre intervention $\mathrm{p} \leq 0.05$ while there was a highly statistically significant relation between total knowledge score and years of studied nurses' experience in intensive care units $\mathrm{P} \leq 0.001$ at Pre-intervention phase

Figure (2): Displays that, $27.5 \%$ of studied nurses had satisfactory level of practices related to prevention of venous thromboembolism 


\section{Effect of An Educational Program on Nurses' Performance regarding Prevention of Venous}

\section{Thromboembolism among Critically Ill Patients}

among critically ill patients at preprogram intervention, which improved to $78.3 \%$ post program intervention.

Table (4): Clarifies that, there was statistically significant relation between total practices score regarding prevention of VTE among critically ill patients, age and qualification of the studied nurses' $\mathrm{p} \leq 0.05$, while there was a highly statistically significant relation between total practices score and years of studied nurses' experience in intensive care units $\mathrm{P} \leq 0.001$ preprogram intervention. While, there was no statistically significant relation between total practices score and personal characteristics of the studied nurses' at post program intervention phase

$\mathrm{P}>0.05$.

Table (5): Clarifies that; there was a highly positive statistical correlation between total knowledge and total practices regarding prevention of venous thromboembolism among critically ill patients post program intervention $\mathrm{P} \leq 0.001$.

Table (1): Distribution of the studied nurses' according to their personal characteristics $(\mathrm{N}=120)$.

Age

Residence

Marital status

Qualification
Personal characteristics

$<25$

20-35

$>35$

$$
\text { Mean } \pm \mathrm{SD}=\mathbf{2 8 . 8 2} \pm 1.36
$$

Male

Female

Rural

Urban

Single

Married

Secondary Technical Nursing

Technical Nursing Institute

Bachelor of Nursing

Postgraduate studies

Years of experience in $<5$ years

5 - 10 years

$>10$ years

Training course about Yes

methods of preventing

Number of courses

Policies, guides or booklet

No

One course

Two courses

No

$\begin{array}{ll}\text { No } & \text { \% } \\ 46 & 38.3 \\ 59 & 49.2 \\ 15 & 12.5\end{array}$

12.5

14.2

85.8

60.8

39.2

19.2

80.8

26.7

34.2

20.8

18.3

28.3

50.0

21.7

10.0

90.0

$108 \quad 90.0$

$\begin{array}{ll}11 & 91.7\end{array}$

$1 \quad 8.3$

100.0 


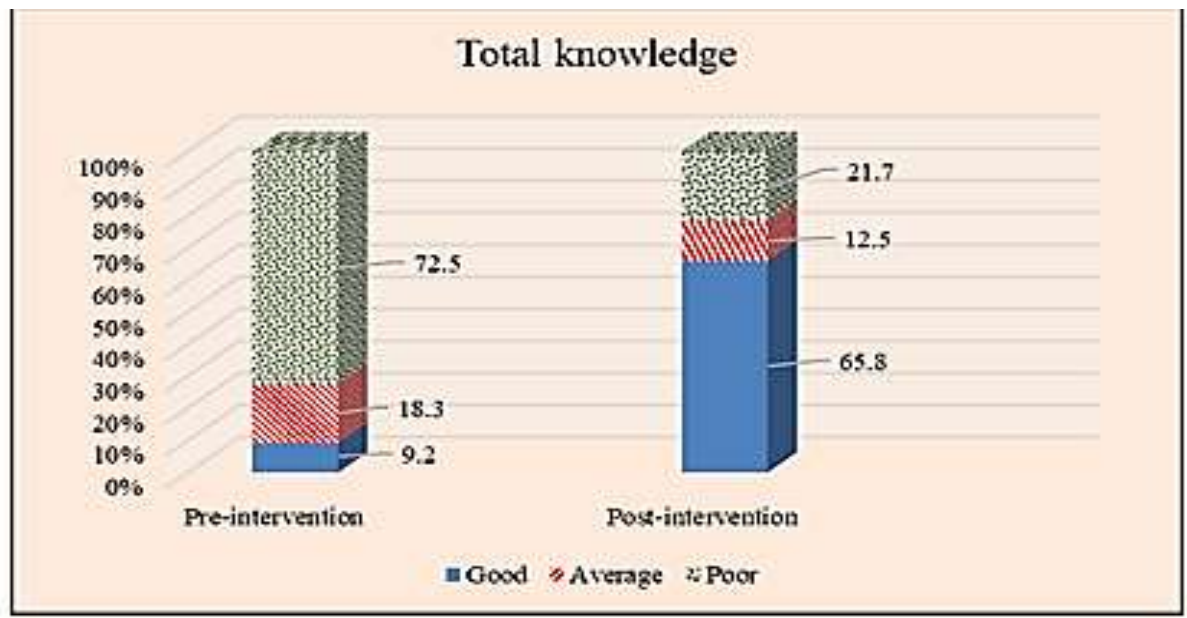

Figure 1: Total knowledge scores among studied nurses regarding prevention of VTE pre and post educational program $(n=120)$

Table 2: mean score and standard deviation Studied nurses' practices regarding prevention of VTE among critically ill patients pre and post educational program $(n=120)$

\begin{tabular}{|c|c|c|c|c|c|c|}
\hline \multirow{2}{*}{ Practices regarding } & \multicolumn{2}{|c|}{ Pre-intervention } & \multicolumn{2}{|c|}{ post-intervention } & \multirow{2}{*}{ t test } & \multirow{2}{*}{ p-value } \\
\hline & Mean & \pm SD & Mean & \pm SD & & \\
\hline $\begin{array}{l}\text { Risk assessment among patients who have } \\
\text { risk for VTE }\end{array}$ & 1.20 & 0.787 & 2.33 & 0.748 & 11.343 & $\leq 0.001 * *$ \\
\hline $\begin{array}{l}\text { Risk assessment for leg and pulmonary } \\
\text { embolism prevention of VTE }\end{array}$ & 6.18 & .0755 & 9.01 & 0.898 & 26.44 & $\leq 0.001 * *$ \\
\hline $\begin{array}{l}\text { Risk assessment for prevention of VTE } \\
\text { and care of patients with VTE }\end{array}$ & 6.50 & 0.766 & 10.07 & 1.11 & 28.913 & $\leq 0.001 * *$ \\
\hline $\begin{array}{l}\text { Care of VTE patients who receiving } \\
\text { anticoagulation therapy }\end{array}$ & 6.93 & 1.18 & 11.19 & 1.54 & 23.934 & $\leq 0.001 * *$ \\
\hline $\begin{array}{l}\text { Teaching discharge plan for high risk } \\
\text { patients }\end{array}$ & 7.01 & 1.63 & 11.24 & 2.03 & 17.697 & $\leq 0.001 * *$ \\
\hline Injection of anticoagulants & 7.50 & 1.44 & 12.75 & 1.30 & 29.558 & $\leq 0.001 * *$ \\
\hline $\begin{array}{l}\text { Obtaining leg measurements to detect early } \\
\text { swelling }\end{array}$ & 6.90 & 1.36 & 9.60 & 1.01 & 17.322 & $\leq 0.001 * *$ \\
\hline Applying compression stocking & 5.38 & 1.189 & 10.19 & 1.006 & 29.558 & $\leq 0.001 * *$ \\
\hline $\begin{array}{l}\text { Active and passive range of motion } \\
\text { exercises (ROM) }\end{array}$ & 37.68 & 4.456 & 67.166 & 3.945 & 53.921 & $\leq 0.001 * *$ \\
\hline Assisting the patients in ambulation & 6.74 & 1.14 & 12.28 & 2.01 & 26.149 & $\leq 0.001 * *$ \\
\hline Total & 92.24 & 7.36 & 155.85 & 6.33 & $71 . .743$ & $\leq 0.001 * *$ \\
\hline
\end{tabular}

**A Highly Statistical significant $\mathrm{p} \leq 0.001$ 
Table (3): Relation between total knowledge score regarding prevention of VTE and personal characteristics of the studied nurses' pre and post educational program $(\mathrm{N}=120)$

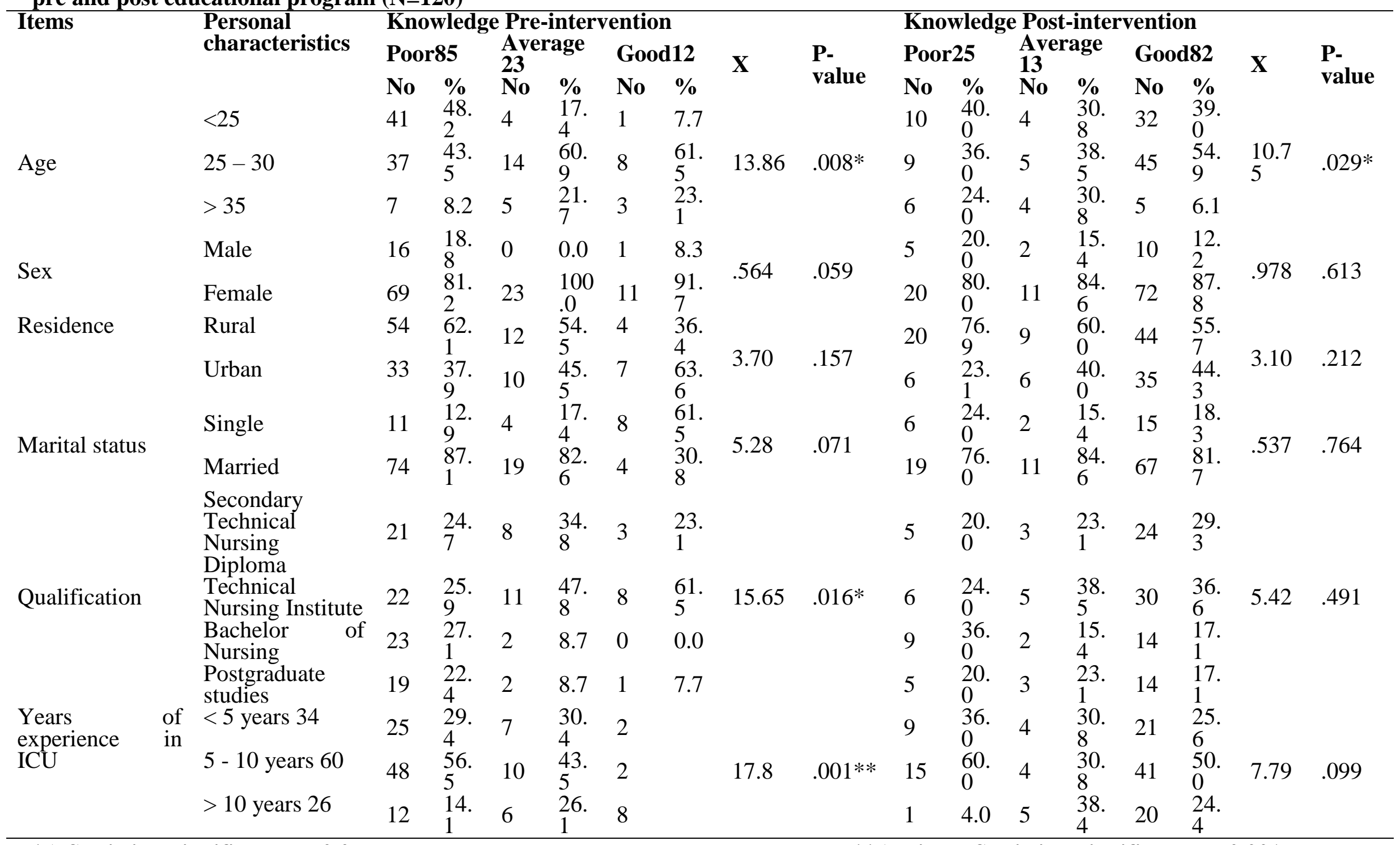

*A Statistical significant $\mathbf{p} \leq \mathbf{0 . 0 5}$

**A Highly Statistical significant $\mathbf{p} \leq \mathbf{0 . 0 0 1}$ 


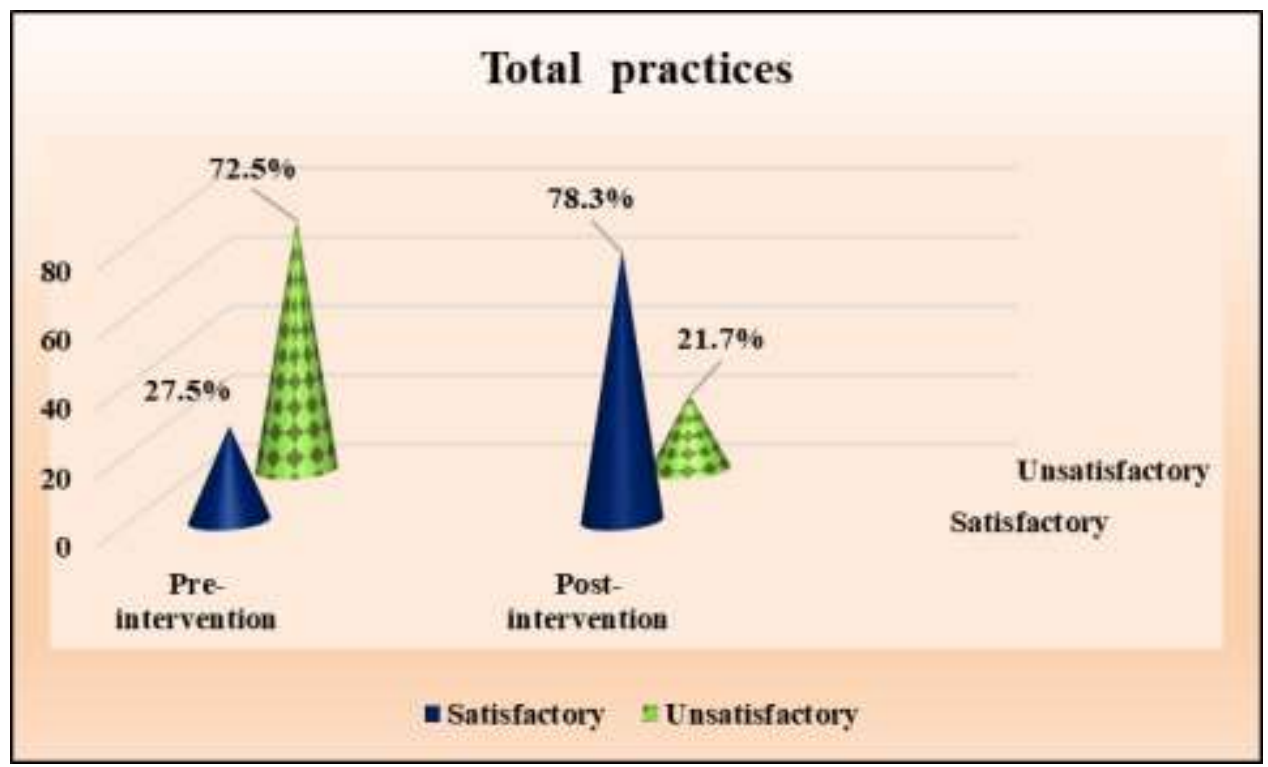

Figure 2: Total practices score of studied nurses regarding prevention of VTE among critically ill patients' pre and post educational program $(n=120)$ 


\section{Thromboembolism among Critically Ill Patients}

Table 4: Relation between total practices score related to prevention of VTE among critically ill patients and selected personal characteristics of the studied nurses' pre and post educational program $(\mathrm{N}=120)$

\begin{tabular}{|c|c|c|c|c|c|c|c|c|c|c|c|c|c|}
\hline \multirow{4}{*}{ Items } & \multirow{4}{*}{$\begin{array}{l}\text { Personal } \\
\text { characteristics }\end{array}$} & \multicolumn{6}{|c|}{ Total Practices Pre-Intervention } & \multicolumn{6}{|c|}{ Total Practices Post-Intervention } \\
\hline & & \multirow{2}{*}{\multicolumn{2}{|c|}{$\begin{array}{l}\text { Satisfacto } \\
\text { ry37 }\end{array}$}} & \multirow{2}{*}{\multicolumn{2}{|c|}{$\begin{array}{l}\text { Unsatisfa } \\
\text { ctory } 83\end{array}$}} & \multirow{3}{*}{$\begin{array}{l}\text { Chi } \\
- \\
\text { squ } \\
\text { are } \\
\text { test }\end{array}$} & \multirow{3}{*}{$\begin{array}{l}\text { P- } \\
\text { value }\end{array}$} & \multirow{2}{*}{\multicolumn{2}{|c|}{$\begin{array}{l}\text { Satisfact } \\
\text { ory98 }\end{array}$}} & \multirow{2}{*}{\multicolumn{2}{|c|}{$\begin{array}{l}\text { Unsatisfa } \\
\text { ctory } 22\end{array}$}} & \multirow{3}{*}{$\begin{array}{l}\text { Chi } \\
- \\
\text { squ } \\
\text { are } \\
\text { test }\end{array}$} & \multirow{3}{*}{$\begin{array}{l}\text { P- } \\
\text { val } \\
\text { ue }\end{array}$} \\
\hline & & & & & & & & & & & & & \\
\hline & & No & $\%$ & No & $\%$ & & & No & $\%$ & No & $\%$ & & \\
\hline & $<25$ & 6 & 16.2 & 40 & 1.1 & & & 37 & $\begin{array}{l}37 . \\
8\end{array}$ & 9 & 40.9 & & \\
\hline \multirow[t]{2}{*}{ Age } & $25-30$ & 25 & 67.6 & 34 & 41.0 & \multirow[t]{2}{*}{$\begin{array}{l}11 . \\
1\end{array}$} & \multirow[t]{2}{*}{$.004^{*}$} & 48 & $\begin{array}{l}49 . \\
0\end{array}$ & 11 & 50.0 & \multirow[t]{2}{*}{.301} & \multirow[t]{2}{*}{$\begin{array}{l}.86 \\
0\end{array}$} \\
\hline & $>35$ & 6 & 16.2 & 9 & 10.8 & & & 13 & $\begin{array}{l}13 . \\
2\end{array}$ & 2 & 9.1 & & \\
\hline \multirow[t]{2}{*}{ Sex } & Male & 6 & 61.2 & 11 & 13.3 & \multirow{2}{*}{$\begin{array}{l}.18 \\
5\end{array}$} & \multirow{2}{*}{.667} & 13 & $\begin{array}{l}13 . \\
3\end{array}$ & 4 & 18.2 & \multirow{2}{*}{.357} & \multirow{2}{*}{$\begin{array}{l}.55 \\
0\end{array}$} \\
\hline & Female & 31 & 83.8 & 72 & 86.7 & & & 85 & $\begin{array}{l}86 . \\
7\end{array}$ & 18 & 81.8 & & \\
\hline \multirow[t]{2}{*}{ Residence } & Urban & 14 & 42.4 & 36 & 41.4 & \multirow{2}{*}{$\begin{array}{l}.36 \\
5\end{array}$} & \multirow{2}{*}{.546} & 38 & $\begin{array}{l}40 . \\
4\end{array}$ & 9 & 34.6 & \multirow[b]{2}{*}{.034} & \multirow{2}{*}{$\begin{array}{l}.85 \\
3\end{array}$} \\
\hline & Rural & 19 & 57.6 & 51 & 58.6 & & & 56 & $\begin{array}{l}59 . \\
6\end{array}$ & 17 & 65.4 & & \\
\hline \multirow{3}{*}{$\begin{array}{l}\text { Marital } \\
\text { status }\end{array}$} & Single & 7 & 45.9 & 16 & 19.3 & \multirow{2}{*}{$\begin{array}{l}.00 \\
2\end{array}$} & \multirow{2}{*}{.963} & 79 & $\begin{array}{l}80 . \\
6 \\
11\end{array}$ & 18 & 81.8 & \multirow{2}{*}{.017} & \multirow{2}{*}{$\begin{array}{l}.89 \\
7\end{array}$} \\
\hline & Married & 30 & 81.1 & 67 & 80.7 & & & 19 & $\begin{array}{l}19 . \\
4\end{array}$ & 4 & 18.2 & & \\
\hline & $\begin{array}{l}\text { Secondary } \\
\text { Technical } \\
\text { Nursing Diploma }\end{array}$ & 32 & 86.5 & 0 & 0.0 & & & 23 & $\begin{array}{l}23 . \\
5\end{array}$ & 9 & 40.9 & & \\
\hline Qualificati & $\begin{array}{l}\text { Technical } \\
\text { Nursing Institute }\end{array}$ & 21 & 56.8 & 20 & 24.1 & 22. & $\begin{array}{l}.000 * \\
*\end{array}$ & 37 & $\begin{array}{l}37 . \\
8\end{array}$ & 4 & 18.2 & 4.1 & .25 \\
\hline & $\begin{array}{l}\text { Bachelor } \\
\text { Nursing }\end{array}$ & 18 & 48.6 & 7 & 8.4 & & & 20 & $\begin{array}{l}20 . \\
4\end{array}$ & 5 & 22.7 & & \\
\hline & $\begin{array}{l}\text { Postgraduate } \\
\text { studies }\end{array}$ & 10 & 27.1 & 12 & 14.5 & & & 18 & $\begin{array}{l}18 . \\
3\end{array}$ & 4 & 18.2 & & \\
\hline $\begin{array}{l}\text { Years of } \\
\text { experienc }\end{array}$ & $<5$ years & 2 & 5.4 & 32 & 38.6 & & & 27 & $\begin{array}{l}27 . \\
6\end{array}$ & 7 & 31.8 & & \\
\hline $\mathrm{e}$ in ICU & $5-10$ years & 25 & 67.6 & 35 & 42.2 & $\begin{array}{l}13 . \\
9\end{array}$ & $\begin{array}{l}.001 * \\
*\end{array}$ & 50 & $\begin{array}{l}51 . \\
0\end{array}$ & 10 & 45.5 & .241 & $\begin{array}{l}.88 \\
7\end{array}$ \\
\hline & $>10$ years & 10 & 27.0 & 16 & 19.2 & & & 21 & $\begin{array}{l}21 . \\
4\end{array}$ & 5 & 22.7 & & \\
\hline
\end{tabular}

*A Statistical significant $\mathbf{p} \leq \mathbf{0 . 0 5}$

**A Highly Statistical significant $\mathbf{p} \leq \mathbf{0 . 0 0 1}$

Table 5: Correlation coefficient between total knowledge and total practices score of the studied nurses' regarding prevention of VTE pre and post educational program $(n=120)$

\begin{tabular}{|c|c|c|c|c|}
\hline \multirow[b]{3}{*}{ Variables } & \multirow{2}{*}{\multicolumn{2}{|c|}{$\begin{array}{l}\text { Total knowledge } \\
\text { Pre }\end{array}$}} & \multirow{2}{*}{ Post } & \multirow[b]{3}{*}{ P-value } \\
\hline & & & & \\
\hline & $\begin{array}{l}r \\
0128\end{array}$ & P-value & & \\
\hline
\end{tabular}




\section{Discussion}

Prevention of VTE is considered a patient's safety measure in the most mandated quality initiatives and importance of nursing role. The measures for prevention of VTE include mechanical methods (graduated compression stockings and intermittent pneumatic compression devices) and pharmacological agents George, et al., (2020).

Regarding age, the result of the present study revealed that the majority of the studied nurses' were in age group between 20-35 years old with mean age of $28.82 \pm 1.36$ years. This result could be due to the nature of work in critical areas that need power and energy to combote the hard work load which is available in young adult nurses. This result agreed with, Ahmed, et al., (2015) in their study titled "Developing nursing care standards for venous thromboembolism (VTE) for patients with orthopedic surgery". Whose results revealed that two thirds of the studied nurses were in age group between 20-30 years old.

Also these results compatible with $\mathbf{O h}$, et al., (2017) \& Abd Elrahman Yones, et al., (2019) revealed that more than half of the studied nurses were in age group between 25-30 years old.

This result disagreed with Mokadem \& El-Sayed, (2019) in their study entitled "Effect of educational intervention on critical care nurses' adherence to the clinical practice guidelines for preventing venous thromboembolism in critically ill patients" whose results revealed that more than half of the studied nurses' age were less than 25 years.
As regard to gender, the current study revealed that most of nurses were females. This result could be due to the fact that most nurses who are working in Benha University Hospital were females. This result is compatible with Elsayedead, et al., (2016), Hebeshy, (2020) \& AL-Jumaily \& Khudur, (2019) revealed that the majority of the nurses' sample was females. This result could be due to the number of female nurses more than males as a result of increasing the acceptance and graduation of females more than males in all educational institutions for nursing in Egypt.

As regard to educational level, the current study revealed that more than one third of the studied nurses had graduated from Technical Institute of Nursing. This result may be due to that most bachelor nurses are working as supervisor or head nurse in the Governmental Hospitals, but technical nurses are working as bedside nurse. In the same line, Hassan \& Hassan, (2016) \& Ahmed, et al., (2020) mentioned that most of his study sample was from the nursing institute.

This result disagreed with Lee et al., (2014) \& Elkattan\& Elderiny, (2017) revealed that slightly more than half of the nurses had bachelor's degree or master degree in nursing. On the other hand more than half of nurses had diploma degree in nursing. This result in the same line with Shehab, (2018).

As regard to nurses' years of experience, the current study revealed that half of the studied nurses had experience between 510 years. This finding could be due to that majority of the nurses were in the age group between 20 to 35 years old. This result consistent with Chen et al., (2018), in their 
study entitled "Nurses' objective knowledge regarding venous thromboembolism prophylaxis" who reported that the mean nursing experience was between $8.96 \pm 7.37$ years.

This result is in the same line with Mohammed, et al., (2018), Yan, et al., (2021) \& Haza, et al., (2020) revealed that near half of the studied nurses had experience between 5-10 years of working in the Intensive Care Units.

\section{Concerning attendance of training} courses This result compatible with Zhou, et al., (2019) in their study entitled " Venous thromboembolism in the emergency department: A survey of current best practice awareness in physicians and nurses in China" whose results revealed that the majority of nurses didn't receive any training courses about venous thromboembolism and its prevention.

The current study reported that there weren't any policies about prevention of venous thromboembolism in their workplace. This result was consistent with Bhatti et al., (2017) who found that the medical / surgical units have no policies for DVT prophylaxis. This result could be due to lack of nurses' knowledge and practice because there was no any standard to develop their knowledge and practice about prevention of venous thromboembolism. The standard for special care required to develop specific written policies and procedures.

Finally regarding to the present study reported that the studied nurses had no booklet about venous thromboembolism; this was congruent with Gad\& El-sheikh, (2016) in their study entitled "Effect of mechanical measures on prevention of deep vein thrombosis among general surgical patients". This result may be occurred because lack of availability of books by the hospital with absent of ICU library and the nurses hadn't time for reading due to workload.

Concerning studied nurses' knowledge, the study results revealed that there were highly statistical significant difference between studied nurses' knowledge related to definition, incidence, risk factors, diagnosis, required investigation and complications of venous thromboembolism pre and post educational program, favoring post educational program. From the researchers' point of view the reasons for lack of nurses' knowledge regarding venous thromboembolism might be related to lack of continuing educational programs or sessions about this disorder or lack of supervision, continuous evaluation of nurses' practice, and cooperation between multidisciplinary health care team members (nurses - physicians).

These findings supported by Ali \& Hassan, (2016) \& Parveen, et al., (2021) that there were significant difference between pre and post tests for total scores of nurses' knowledge about venous thromboembolism prevention as definition, risk factors, complication, treatment and nursing care for patients with VTE, provided health educational program significantly improved the total knowledge about venous thromboembolism prevention.

This result disagreed with Lavall, (2014) in their study entitled "Increasing public awareness of venous thromboembolism through social media" who reported that no shortage exists of knowledge for healthcare providers 
(nurses and physicians) about venous thromboembolism in Rhode Island at U.S.A.

There was a significant statistical difference between total practice score of the studied nurses' pre and post program intervention favoring post program. This might be due to the absence of a training program, booklet and stander for care inside each unit during the period of program implementation. In the same line with Khalil, (2018) \& Mohammed et al., (2018) reported that this might be related to many factors as nursing workload, lack of availability of assessment tools, lack of education on assessment tools, lack of familiarity with tools, lack of protocols and guidelines management and no designing area for charting.

Related to study nurses' practice score regarding prevention of venous thromboembolism, the study revealed that there were high statistical significant differences between studied nurses' practice score about total practices for prevention of VTE pre and post intervention program, favoring post program. These findings supported by Mokadem, \& El-Sayed, (2019) in their study, whose result stated that there was a significant improvement in the nurses' practice regarding prevention of VTE in post intervention program.

This study disagreed with Mohamed et al., (2017) in their study who found that the majority of nurses had satisfactory level of practice.

The current study revealed that there was a statistically significant relation between total knowledge score regarding prevention of venous thromboembolism among critically ill patients and personal characteristics of the studied nurses' pre and post program intervention.

This study congrunt with Mersal, (2014) in their study entitled" Caregivers' Knowledge and Practice Regarding Prevention of Immobilization Complications in Eldemerdash Hospital Cairo Egypt" whose revealed that a highly and statistically significant difference was found between the personal characteristics and total mean score of knowledge of caregivers regarding prevention of immobility complications. The finding of the present study revealed that policy structure, guideline structure, training session structure, supervision of nurses' performance regarding preventing VTE structure, IPC device supplies structure for preventing VTE, computer programs for electronic alerts for patients at risk of VTE documentation sheet for VTE assessment, application of VTE preventive measures and patient education were not available in hospital structure.

As regarding relations between practice and previous training. These findings supported by AbdEInaeem, (2015) in their study entitled" Effect of implementing cardiopulmonary resuscitation teaching program on knowledge and skills of critical care nurses" who found that nurses receiving previous training obtained a high mean score with the statistically significant difference before implementing the teaching program.

Also, this result agreed with Alhosis et al., (2018) in their study entitled" Effect of designed pressure ulcer prevention program on caregivers' knowledge of immobilized patients" 


\section{Thromboembolism among Critically Ill Patients}

who found a significant relationship between caregivers' socio-demographic characteristics and their total mean knowledge score.

There was a significant statistical difference between total practice score of the studied nurses' pre and post program intervention favoring post program. This might be due to the absence of a training program, booklet and stander for care inside each unit during the period of program implementation. In the same line with Khalil, (2018) who reported that this might be related to many factors as nursing workload, lack of availability of assessment tools, lack of education on assessment tools, lack of familiarity with tools, lack of protocols and guidelines management and no designing area for charting.

This result was incompatible with Alhusaunawy, (2015) \& Kaur \& Charan, (2018) revealed that there were no statistically significant differences between total knowledge score and demographic characteristic the nurses nearly in all items.

Concerned with correlation between total knowledge scores and total practice score of the studied nurses' regarding prevention of VTE among critically ill patients.

These findings agreed with El-sayedead et al., (2016) \& Haza'a, et al., (2020) showed that there was a positive correlation between total nurse's knowledge and total practice scores practice related to deep vein thrombosis pre and post implementation of the education program.

This result disagreed with Antony, (2016) in their study entitled "Assessment of knowledge and self-reported clinical practice on prevention of deep vein thrombosis among staff nurses" whose result revealed that there was no significant association between the knowledge and practice of staff nurses on prevention of DVT among hospitalized patients.

\section{Conclusion}

The educational program has a positive effect in improving nurses' performance and improving mean scores of performance (knowledge and practice) regarding prevention of venous thromboembolism among critically ill patients, which supported the study hypothesis.

\section{Recommendation}

- Conducting continuous training courses on job training for nurses about venous thromboembolism and its prevention among critically ill patients.

- Continuous evaluation for nurses' performance regarding prevention of venous thromboembolism among critically ill patients.

- Standardized venous thromboembolism risk assessment tool should be available and used to assess occurrence of venous thromboembolism.

- Clarification policies and strategies for thromboprophylaxis to be utilized for high risk factors.

- Replication of the study on larger propability sample from different geographic area for generalization of the results.

\section{References}

Abd Elrahman Yones, F. \& Ahmed Qalawa, S. (2019). Assessment Of Nurses' Performance Regarding Caring Of Patients On Anticoagulant Therapy In Port-Said Hospitals. Port Said Scientific Journal of Nursing, 6(3), 1-15. 
Gehad Hussein Amin El-gendy, Manal Hamed Mahmoud and Eman Sobhy Omran

AbdEInaeem, M., (2015). Effect of implementing cardiopulmonary resuscitation teaching program on knowledge and skills of critical care nurses at Assiut University Hospital. Assiut University, 8(4):1-14.

Ahmed, M., Moubarak, M., \& Ghanem, H. (2015). Developing Nursing Care Standards for Venous Thromboembolism (VTE) for Patients with Orthopedic Surgery. Assiut Scientific Nursing Journal, 3(5), 49-58.

Ageno, W., Farjat, A., Haas, S., Weitz, J., Goldhaber, S., Turpie, A., et al. (2021). "Provoked versus unprovoked venous thromboembolism: Findings from GARFIELDVTE". Research and Practice in Thrombosis and Haemostasis. 5 (2): 326-341.

Alhosis, K., Qalawa, S. \& Abd El- Moneem, D. (2018). Effect of designed pressure ulcer prevention program on caregivers' knowledge of immobilized patients. Journal of American Science, 8(12): 939-948.

Al-husaunawy, A. (2015). Evaluation of Nurses Knowledge and Practical of Electrocardiogram Toward Adolescent Patient. IOSR Journal of Nursing and Health Science, 4(4), 10-16. https://doi.org/10.9790/195904421016.

Ali, M., \& Hassan, H., (2016). Effectiveness of Nursing Educational Program on Nurses Knowledge toward Venous Thromboembolism at Ibn Alnafees Teaching Hospital Abstract: IOSR Journal of Nursing and Health Science, 5(5), 27-30. https://doi.org/10.9790/19590505022730 .

AL-Jumaily, A., \& Khudur, K., (2019). Effectiveness of an Education Program on Nurses knowledge concerning in Nursing Management for patients with Third degree and bundle branch block in Kirkuk Teaching
Hospitals. Mosul Journal of Nursing, 7(1), 719.

Antony, A., Moly, K. \& Dharan, D. (2016). Assessment of Knowledge and Self-Reported Clinical Practice on Prevention of Deep Vein Thrombosis (DVT) Among Staff Nurses. Journal of Nursing and Health Science, 5 (1): 18-24.

Bhatti, A., Ahsin, S., Salim, B.,\& Mansoor, J. (2017). Knowledge, attitude and practices of healthcare providers towards deep vein thrombosis prophylaxis in five teaching hospitals of Rawalpindi. J Ayub Med Coll Abbottabad,24(2):136-9. PMID: 24397075.

Chen, Y., Wang, X., Deng, H., \& He, Y., (2018). Nurses ' objective knowledge regarding venous thromboembolism prophylaxis. Www.md-Journal.com, 97(14), 1-7.

Crous-Bou, M., Harrington, L.,\& Kabrhel,C. (2016). "Environmental and genetic risk factors associated with venous thromboembolism". Seminars in Thrombosis and Hemostasis. 42 (8): 808-820.

Eldosoky, E. (2018). Effect of a training program for nurses about preventive measures of deep vein thrombosis. Dectorate thesis, Faculty of nursing, 14(1), 1-17.

Elkattan, B. \& Elderiny, S. (2017). Effect of Nursing Care Guidelines on Preventing Deep Venous Thrombosis among Critically Ill Patients. International Journal of Novel Research in Healthcare and Nursing, 6(2), 757774.

El-sayedead, D., Fouad Abdallah, K., Hegazi, M., \& Mohammed, S. (2016). Effect of Nursing Care Standards for Preventing Deep Vein Thrombosis among Patients Undergoing Hip Surgery on Nurses Performance and Patients Outcome. Journal of Nursing and Health Science, 5(4), 1-12. 


\section{Thromboembolism among Critically Ill Patients}

Gad, S., \& EL-Sheikh, A. (2016). Effect of Mechanical Measures on Prevention of Deep Vein Thrombosis among General Surgical Patients. Med. J. Cairo Univ, 81(1), 1043-1051.

George, B., Gonzales, S., Patel, K., Petit, S., Franck, A. J., \& Bovio Franck, J. (2020). Impact of a clinical decision-support tool on venous thromboembolism prophylaxis in acutely ill medical patients. Journal of Pharmacy Technology, 36(4), 141-147.

Hassan, S., \& Hassan, H., (2016). Effectiveness of Nursing Education Program on Nurses Practices Toward Arrhythmia in Kirkuk Teaching Hospitals. Kufa Journal for Nursing Sciences, 3(1), 220-230.

Haut, E. R. (2017). Effectiveness of two distinct web-based education tools for bedside nurses on medication administration practice for venous thromboembolism prevention: a randomized clinical trial. PLoS One, 12(8), e0181664.

Haza'a, A., Al-Qubati, F.,Mohammed, M.,Abdel-Aziz, M., \& Mehany, M. (2020). Effect of An Educational Program on Critical Care Nurses Performance regarding Emergency Care for Patients with Pulmonary Embolism. Assiut Scientific Nursing Journal, 8(20), 31-44.

Hebeshy, M., Hansen, D., Broome, B., Abou Abdou, S., Murrock, C., \& Bernert, D. (2020). Development of the Nurses' Intention to Use Deep Vein Thrombosis Preventive Measures Questionnaire. Journal of Nursing Measurement.

Kaur, A., \& Charan, G., (2018). A Study to Assess the Effectiveness of STP on Knowledge and Practice Regarding ABGs among ICU Nurses in Selected Hospitals at Jalandhar, Punjab. International Journal of Health Sciences and Research, 8(8), 182-188.
Khalil, N., (2018). Critical care nurses use of non-pharmacological pain management methods in Egypt. Applied Nursing Research, 44, 33-38. https://doi. org/10.1016/j. apnr .2018.09.001.

Klarin, D., Busenkell, E., Judy, R., Lynch, J., Levin, M., Haessler, J., et al. (2019). "Genome-wide association analysis of venous thromboembolism identifies new risk loci and genetic overlap with arterial vascular disease". Nature Genetics. 51 (11): 1574-1579.

Lavall, A., (2014). "Increasing Public Awareness of Venous Thromboembolism Through Social Media". Honors Projects Overview, 10(7),89. https://digitalcommons.ric.edu/honors_projects/ 89

Lavery, J. (2021). Clinical assessment of the leg for a suspected deep vein thrombosis. Nursing Times [online], 117(5), 18-21.

Lee, J., Grochow, D., Drake, D., Johnson, L., Reed, P., \& van Servellen, G. (2014). Evaluation of hospital nurses' perceived knowledge and practices of venous thromboembolism assessment and prevention. Journal of Vascular Nursing, 32(1), 18-24.

Li, N., \& Poor, H. (2021). Venous thromboembolism and pulmonary embolism. Mount Sinai Expert Guides: Critical Care, 20(3):575-585.

Mersal F., (2014). Caregivers' Knowledge and Practice Regarding Prevention of Immobilization Complications in Eldemerdash Hospital Cairo Egypt. American Journal of Research Communication, 30 (3): Pp78-98

Mohamed, A., Othman, W., El Alphy, B., \& Sheble, A., (2017). Effect of Implementing Nursing Care Guidelines on the Occurrence of Deep Vein Thrombosis among Orthopedic 
Gehad Hussein Amin El-gendy, Manal Hamed Mahmoud and Eman Sobhy Omran

Patients. IOSR Journal of Nursing and Health Science; 6(3): pp 28

Mohammed, A., Taha, N., \& Abdel-Aziz, E. (2018). Nurses' Performance Regarding Venous Thromboembolism Prophylaxis at Intensive Care Unit. Zagazig Nursing Journal, 14(1), 117.

Mokadem, N., \&El Sayed, sh. (2019). Effect of Educational Intervention on Critical Care Nurses' Adherence to the Clinical Practice Guidelines for Preventing Venous Thromboembolism in Critically Ill Patients. American Journal of Nursing, 7(6), 974-982.

Nettina, S. (2014). Lippincott manual of nursing practice.10th Ed. Wolters Kluwer Health, Lippincott Williams \&Wilkins, China, Ch.14, P.P. 439, 445; 2014.

Oh, H., Boo, S., \& Lee, J. A. (2017). Clinical nurses' knowledge and practice of venous thromboembolism risk assessment and prevention in South Korea: A cross-sectional survey. Journal of clinical nursing, 26(3-4), 427-435.

Parveen, B., Kousar,H., Parveen, M., \& Afzal, M. (2021). Nurses knowledge and practices regarding risk factors and prevention of patients diagnosed with deep vein thrombosis. Journal of Global Biosciences; 10(6): pp 8780-8800.

Schünemann, H., Cushman, M., Burnett, A., Kahn, S., Beyer-Westendorf, J., Spencer, F., \& Wiercioch, W. (2018). American Society of Hematology guidelines for management of venous thromboembolism: prophylaxis for hospitalized and nonhospitalized medical patients. Blood advances, 2(22), 3198-3225.

Shaaban, A. E. (2021). Effect of Nursing Care Protocol on Deep Vein Thrombosis Occurrence among Critically Neurological Patients. Port
Said Scientific Journal of Nursing, 8(1), 206225.

Shehab, M., (2018). Impact of an Educational Program on Nurses â€TM Knowledge and Practice Regarding Care of Traumatic Brain I njury Patients at Intensive Care Unit at Suez Canal University Hospital. International Journal of Caring Sciences, 11(2), 1104-1116.

Tamowicz, B., Mikstacki, A., Urbanek, T., \& Zawilska, K. (2019). Mechanical methods of venous thromboembolism prevention: from guidelines to clinical practice. Pol Arch Intern Med, 129(5), 335-341.

Tran, H., Gibbs, H., Merriman, E., Curnow, J., Young, L., Bennett, A., et al. (2019). "New guidelines from the Thrombosis and Haemostasis Society of Australia and New Zealand for the diagnosis and management of venous thromboembolism". The Medical Journal of Australia. 210 (5): 227-235.

Yan, T., He, W., Hang, C., Qin, L., Qian, L., Jia, Z. \& Xu, Y. (2021). Nurses' knowledge, ttitudes, and behaviors toward venous thromboembolism prophylaxis: How to do better. Vascular, 29(1), 78-84.

Zhou, W., He, J. ,Guo, S., Walline, J., Liu, X., Tian, L., \& Li, Y. (2019). Venous thromboembolism in the emergency department: A survey of current best practice awareness in physicians and nurses in China. World journal of emergency medicine, 10(1), 5. 
تأثير البرنامج التعليمي على أداء الممرضين فيما يتعلق بالوقاية من الجلطات الاموية الوريدية لاى مرضى الحالات الحرجة

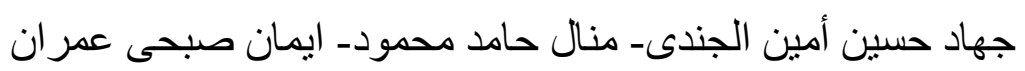

تعتبر الجلطات الدموية الوريدية هى أحد المضاعفات الثائعة للامراض الخطيرة ، بما في ذلك الإصابة بجلطات الأوردة العميقة والانسداد الرئوي، وهى سبب رئيسي للوفيات المتعلقة بالمستثفيات في جميع اهئ

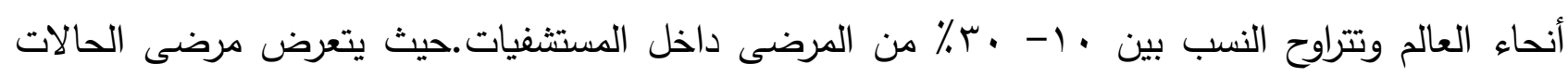
الحرجة لخطر كبير للإصابة بجلطات الأوردة العميقة ويجب الحد من انتثار الإصابة بجلطات الأوردة العميقة

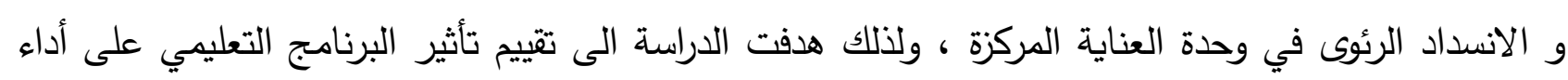

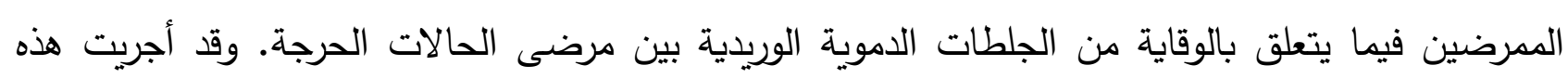

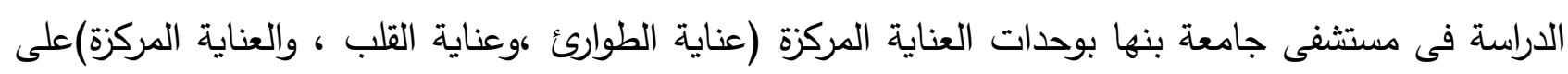

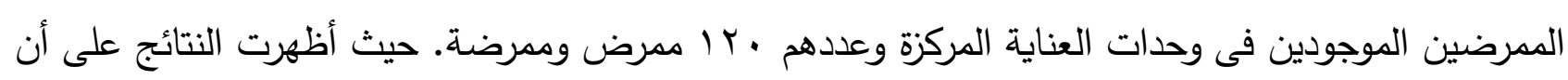
هناك فروق ذات دلالات إحصائية بين معلومات الممرضين ومهارتهم عن الوقاية من الجلطات الدموية الوريدية وتحسن معلومات ومهارات الممرضين بعد تلقيهم البرنامج التعليمى.كما أظهرت أن البرنامج التعليمي لله تأثير الثرن

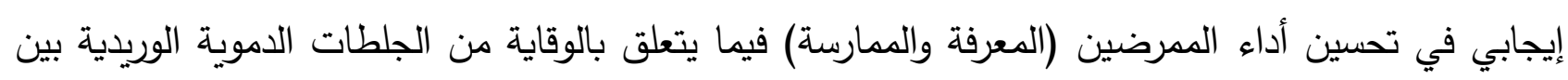

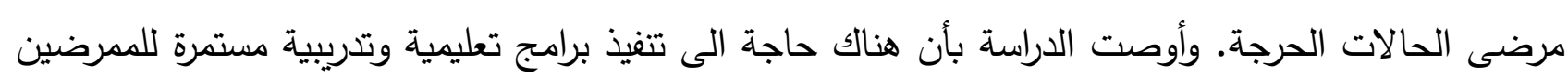
فيما يتعلق بالوقاية من الجلطات الدموية الوريدية بين مرضى الحالات الحرجة. 